Patryk Zradziński

PRACA ORYGINALNA

Jolanta Karpowicz

Krzysztof Gryz

Wiesław Leszko

\title{
OCENA ZAGROŻEŃ
}

\section{WYNIKAJĄCYCH Z ODDZIAŁYWANIA POLA MAGNETYCZNEGO EMITOWANEGO PRZEZ APLIKATOR MAGNETOTERAPEUTYCZNY DLA UŻYTKOWNIKÓW PROTEZ SŁUCHU WYKORZYSTUJĄCYCH PRZEWODNICTWO KOSTNE}

\author{
EVALUATION OF HAZARDS CAUSED BY MAGNETIC FIELD EMITTED FROM MAGNETOTHERAPY APPLICATOR \\ TO THE USERS OF BONE CONDUCTION HEARING PROSTHESES
}

Centralny Instytut Ochrony Pracy - Państwowy Instytut Badawczy / Central Institute for Labour Protection - National Research Institute, Warszawa, Poland

Pracownia Zagrożeń Elektromagnetycznych / Laboratory of Electromagnetic Hazards

\begin{abstract}
STRESZCZENIE
Wstęp: Pole magnetyczne małej częstotliwości, wywołując wewnątrz struktur elektrycznie przewodzących indukowane pole elektryczne $\left(\mathrm{E}_{\mathrm{in}}\right)$, może bezpośrednio oddziaływać na funkcjonowanie organizmu, np. poprzez elektrostymulację układu nerwowego. Ponadto rozkład przestrzenny i natężenie $\mathrm{E}_{\text {in }}$ są zaburzone w sąsiedztwie elektroprzewodzących struktur implantu medycznego. Materiał i metody: Opracowano numeryczne modele aplikatora do magnetoterapii, będącego źródłem pola magnetycznego sinusoidalnie zmiennego o częstotliwości $100 \mathrm{~Hz}$, oraz użytkownika częściowo implantowanej protezy słuchu (implantu słuchowego wykorzystującego przewodnictwo kostne: typu Bonebridge (IS-BB) lub implantu słuchowego typu BAHA (IS-BAHA - bone anchored hearing aid, implant słuchu zakotwiczony w kości). Przeanalizowano wartości $\mathrm{E}_{\text {in }} \mathrm{w}$ modelu głowy użytkownika implantu przebywającego obok aplikatora (np. fizjoterapeuty). Wyniki: Wykazano, że używanie IS-BB lub IS-BAHA istotnie zwiększa (do ok. 4-krotnie) zagrożenia elektromagnetyczne jego użytkownika w porównaniu z osobą bez implantu, narażoną na niejednorodne przestrzennie pole magnetyczne. Zagrożenie dla użytkownika IS-BAHA jest większe niż użytkownika IS-BB. Stwierdzono, że przy zastosowaniu zasad oceny określonych w Dyrektywie 2013/35/UE w przypadku użytkowników implantów słuchowych przy narażeniu na pole niejednorodne słabsze od limitów indukcji magnetycznej może wystąpić przekroczenie limitów natężenia pola indukowanego w organizmie. Natomiast w przypadku stosowania wymagań i limitów określonych w polskim prawie pracy lub zaleceniach ICNIRP (International Commission on Non-Ionizing Radiation Protection - Międzynarodowa Komisja ds. Ochrony Przed Promieniowaniem Niejonizującym) dotrzymanie wymagań dotyczących poziomu ekspozycji zapewnia również dotrzymanie wymagań dotyczących odpowiednich limitów pola indukowanego w organizmie użytkownika implantu słuchowego. Wnioski: Konieczne jest wykonanie indywidualnej oceny zagrożeń elektromagnetycznych dotyczących użytkowników implantów słuchowych ze względu na stwierdzone istotnie większe zagrożenia w stosunku do osób bez implantu oraz różnic w poziomie zagrożenia użytkowników implantów o odmiennych rozwiązaniach konstrukcyjnych czy technologicznych. Med. Pr. 2017;68(4):469-477
\end{abstract}

Słowa kluczowe: symulacje numeryczne, pola elektromagnetyczne, implanty słuchowe, przewodnictwo kostne, indukowane pole elektryczne, Dyrektywa 2013/35/UE

\begin{abstract}
Background: Low frequency magnetic field, inducing electrical field $\left(\mathrm{E}_{\text {in }}\right)$ inside conductive structures may directly affect the human body, e.g., by electrostimulation in the nervous system. In addition, the spatial distribution and level of $\mathrm{E}_{\text {in }}$ are disturbed in tissues neighbouring the medical implant. Material and Methods: Numerical models of magneto-therapeutic applicator (emitting sinusoidal magnetic field of frequency $100 \mathrm{~Hz}$ ) and the user of hearing implant (based on bone conduction: Bonebridge type - IS-BB or BAHA (bone anchorde hearing aid) type - IS-BAHA) were worked out. Values of $\mathrm{E}_{\text {in }}$ were analyzed in the model of the implant user's head, e.g., physiotherapist, placed next to the applicator. Results: It was demonstrated that the use of IS-BB or IS-BAHA makes electromagnetic hazards significantly higher (up to 4-fold) compared to the person without implant exposed to magnetic field heterogeneous in space. Hazards for IS-BAHA users are higher than those for IS-BB users. It was found that applying the principles of directive 2013/35/EU, at exposure to magnetic field below exposure limits the direct biophysical effects of
\end{abstract}

Finansowanie / Funding: publikacja opracowana na podstawie wyników III etapu programu wieloletniego pn. „Poprawa bezpieczeństwa i warunków pracy” finansowanego w latach 2014-2016 w zakresie badań naukowych i prac rozwojowych ze środków Ministerstwa Nauki i Szkolnictwa Wyższego, Narodowego Centrum Badań i Rozwoju (projekt II.P.14). Koordynator programu: Centralny Instytut Ochrony Pracy - Państwowy Instytut Badawczy. Kierownik projektu: dr inż. Patryk Zradziński. 
exposure in hearing prosthesis users may exceed relevant limits. Whereas applying principles and limits set up by Polish labor law or the International Commission on Non-Ionizing Radiation Protection (ICNIRP) guidelines, the compliance with the exposure limits also ensures the compliance with relevant limits of electric field induced in the body of hearing implant user. Conclusions: It is necessary to assess individually electromagnetic hazard concerning hearing implant users bearing in mind significantly higher hazards to them compared to person without implant or differences between levels of hazards faced by users of implants of various structural or technological solutions. Med Pr 2017;68(4):469-477

Key words: numerical simulations, electromagnetic fields, hearing implants, bone conduction, induced electric field, Directive 2013/35/EU

Autor do korespondencji / Corresponding author: Patryk Zradziński, Centralny Instytut Ochrony Pracy -

Państwowy Instytut Badawczy, Pracownia Zagrożeń Elektromagnetycznych, ul. Czerniakowska 16, 00-701 Warszawa, e-mail: pazra@ciop.pl

Nadesłano: 17 listopada 2015, zatwierdzono: 22 września 2016

\section{WSTĘP}

Wspomaganie funkcji życiowych organizmu poprzez stosowanie różnego typu aktywnych wszczepialnych wyrobów medycznych (active implantable medical devices - AIMD) jest obecnie gwałtownie rozwijającą się dziedziną inżynierii medycznej [1]. Szybko wzrasta zróżnicowanie terapeutyczne takich urządzeń i liczba ich użytkowników, obejmując problemy z niedosłuchem kompensowane przez różnego rodzaju wyroby elektroniczne [2-6].

Dla pracowników używających AIMD oddziaływanie pola elektromagnetycznego może być czynnikiem zwiększającym zagrożenie zdrowia $\mathrm{w}$ miejscu pracy w stosunku do pozostałych osób, a więc istotnym przeciwwskazaniem do zatrudnienia w pobliżu jego źródeł [4]. Wymagania Dyrektywy 2013/35/UE w sprawie minimalnych wymagań w zakresie ochrony zdrowia i bezpieczeństwa dotyczących zagrożeń pracowników spowodowanych czynnikami fizycznymi (polami elektromagnetycznymi) obejmują rozpatrzenie zagrożeń elektromagnetycznych dla użytkowników implantów medycznych w miejscu pracy - w ramach ochrony pracowników szczególnie zagrożonych (workers at particular risks) i w zakresie opieki medycznej (health surveillance), a także dostosowanie środków ochronnych oraz zakresu szkolenia i informowania pracowników do dotyczących ich zagrożeń $[7,8]$. Analogiczne wymagania wprowadza transponujące dyrektywę polskie prawo pracy $[9,10]$.

\section{Cel badań}

Celem prezentowanych badań była ocena porównawcza skali bezpośrednich zagrożeń elektromagnetycznych dla użytkowników częściowo implantowanych protez słuchu, tj. implantów słuchowych wykorzystujących przewodnictwo kostne typu Bonebridge (IS-BB) i typu BAHA (IS-BAHA - bone anchored hearing aid, implant słuchu zakotwiczony w kości). Zagrożenia te przeanalizowano na przykładzie pracowników, którzy wykonują pracę fizjoterapeuty przy urządzeniach magnetoterapeutycznych. Uwzględniono specyfikę zasad oceny zagrożeń bezpośrednich wg ICNIRP (International Commission on Non-Ionizing Radiation Protection - Międzynarodowa Komisja ds. Ochrony Przed Promieniowaniem Niejonizującym) [11], Dyrektywy 2013/35/UE [7] i polskiego prawa pracy $[9,10]$.

\section{MATERIAt I METODY}

Wcześniejsze badania dotyczące użytkowników IS-BB podlegających oddziaływaniu pola magnetycznego przy aplikatorach o różnej wielkości wykazały większe względne zagrożenia przy aplikatorach o mniejszej średnicy, emitujących pole o większym zróżnicowaniu przestrzennym [12]. Prezentowane badania dotyczyły w związku z tym aplikatorów o średnicy $25 \mathrm{~cm}$, najmniejszych wśród urządzeń popularnych w polskich placówkach fizykoterapeutycznych [13].

Przeprowadzono symulacje numeryczne biofizycznych skutków oddziaływania pola elektromagnetycznego na użytkownika AIMD, tj. wartości natężenia indukowanego pola elektrycznego $\left(\mathrm{E}_{\text {in }}\right)$, $\mathrm{z}$ wykorzystaniem opracowanych numerycznych modeli, odwzorowujących budowę IS-BB oraz IS-BAHA i ich położenie $\mathrm{w}$ uproszczonym modelu ciała. Wyniki symulacji oceniono $\mathrm{w}$ oparciu o kryteria podane w zaleceniach ICNIRP, będących podstawą kryteriów podanych w Dyrektywie 2013/35/UE i polskim prawie pracy $[7,10,11]$.

\section{Analizowany scenariusz ekspozycyjny}

Magnetoterapię wykonuje się najczęściej z użyciem emitujących pole magnetyczne małej częstotliwości 
aplikatorów (cewek szpulowych) zasilanych prądem o regulowanych natężeniach i częstotliwości, najczęściej z zakresu $1-100 \mathrm{~Hz}$, zapewniających emisję pola o indukcji 0-20 mT [13].

Fizjoterapeuta układa pacjenta wewnątrz aplikatora, ustawia parametry pola magnetycznego i uruchamia jego emisję. Podchodząc do pacjenta podczas zabiegu (kiedy aplikator jest aktywny), fizjoterapeuta jest narażony na niejednorodne przestrzennie pole magnetyczne rozproszone w otoczeniu aplikatora (ryc. 1a). Przy omawianym aplikatorze poziom narażenia raptownie zmniejsza się $\mathrm{w}$ miarę oddalania od jego obudowy, np. ok. 10-krotnie w odległości $30 \mathrm{~cm}$ (ryc. 1b).

Analiza zagrożeń elektromagnetycznych użytkowników IS-BB i IS-BAHA dotyczyła oddziaływania sinusoidalnie zmiennego $\mathrm{w}$ czasie pola elektromagnetycznego o najwyższej w typowych urządzeniach częstotliwości $100 \mathrm{~Hz}$ - ze względu na proporcjonalność do częstotliwości elektrodynamicznych skutków oddziaływania takiego pola. Badania wykonano z zastosowaniem modelu numerycznego aplikatora urządzenia magnetoterapeutycznego typu Magnetronic (prod. Elektronika i Elektromedycyna, Polska) o średnicy $25 \mathrm{~cm}$ i szerokości $20 \mathrm{~cm}$.

a)

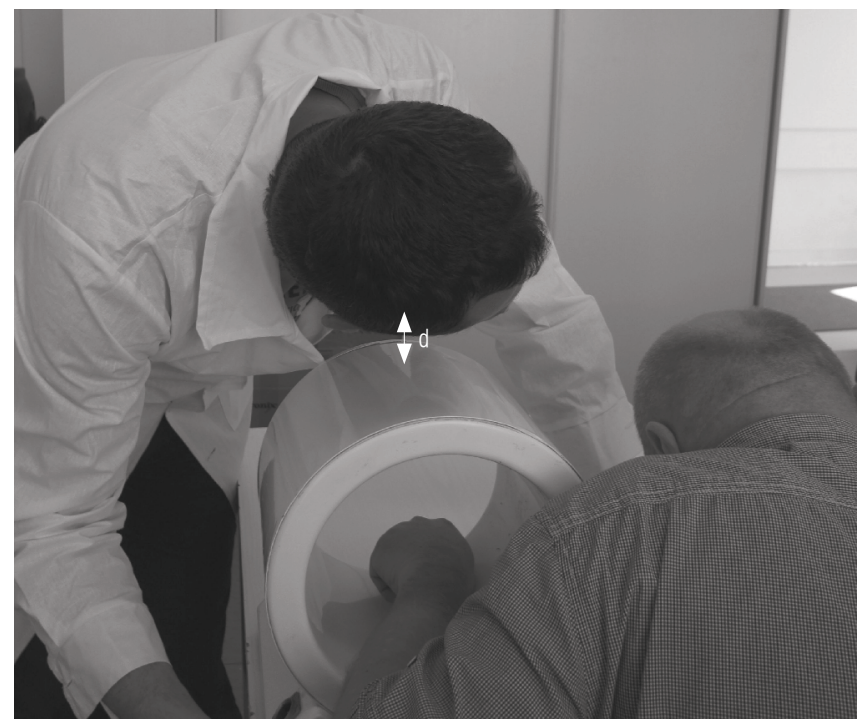

W analizowanych modelach powierzchnia modelu głowy użytkownika implantu znajdowała się z boku aplikatora w odległości $2 \mathrm{~cm}$, gdzie występuje silne i niejednorodne pole magnetyczne. W scenariuszu tym główna oś numerycznego modelu głowy była prostopadła do promienia aplikatora (polaryzacja pola równoległa do płaszczyzn strzałkowych modelu głowy). W takiej konfiguracji występuje najsilniejsze oddziaływanie pola emitowanego przez aplikator na użytkownika implantu [12].

\section{Numeryczne modele analizowanych implantów}

Implanty słuchowe typu IS-BB i IS-BAHA są przeznaczone dla osób dotkniętych jednostronną głuchotą, ubytkiem słuchu typu przewodzeniowego lub mieszanego, czyli takiego, który wynika $\mathrm{z}$ wrodzonego lub nabytego uszkodzenia ucha zewnętrznego, środkowego lub wewnętrznego [6].

Modele numeryczne opracowano na podstawie danych technicznych producentów implantów - dla IS-BB z firmy MED-EL, natomiast dla IS-BAHA z firmy Cochlear. W numerycznych modelach obu implantów uwzględniono wymiary, kształt i parametry materiałowe (przewodność i względną przenikalność elektryczną) elementów zarówno części zewnętrznej, jak i we-

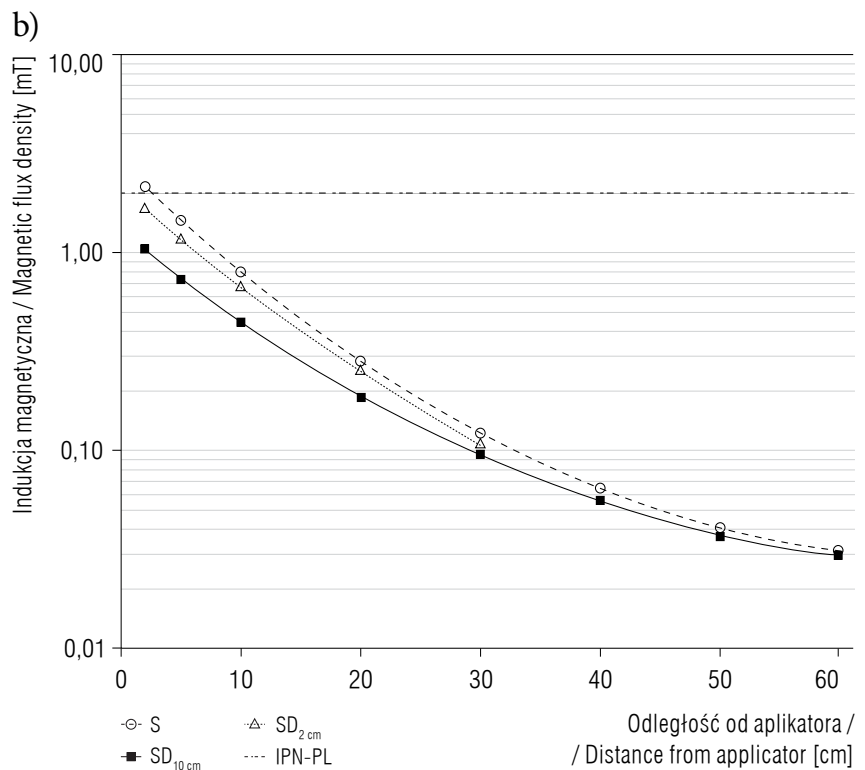

d - odległość między najbliżej położonymi powierzchniami głowy pracownika i aplikatora / distance between the nearest surfaces of workers' head and an applicator, $\mathrm{S}$ - wyniki symulacji wartości punktowej / results of point values simulation, $\mathrm{SD}_{2 \mathrm{~cm}}$ - wyniki pomiarów sondą o długości krawędzi ok. $2 \mathrm{~cm} /$ results of measurements using a probe with an edge length approx. $2 \mathrm{~cm}, \mathrm{SD}_{10 \mathrm{~cm}}$ - wyniki pomiarów sondą o długości krawędzi ok. $10 \mathrm{~cm} /$ results of measurements using a probe with an edge length approx. $10 \mathrm{~cm}$, IPN-PL - limit narażenia według polskiego prawa pracy / limit of exposure according to labor legislation in Poland [9,10].

Ryc. 1. Scenariusz ekspozycyjny oddziaływania pola magnetycznego na pracownika: a) pozycja pracownika podczas pochylania się do pacjenta poddawanego zabiegowi magnetoterapeutycznemu, b) rozkład pola magnetycznego w funkcji odległości od obudowy aplikatora dla maksymalnych nastaw parametrów emitowanego sinusoidalnego pola magnetycznego

Fig. 1. Exposure scenario of magnetic field effects on a worker: a) the posture of worker who is leaning to the patient during magnetotherapy, b) magnetic field distribution in the function of distance from an applicator, for maximum settings of emitted magnetic field 
a)

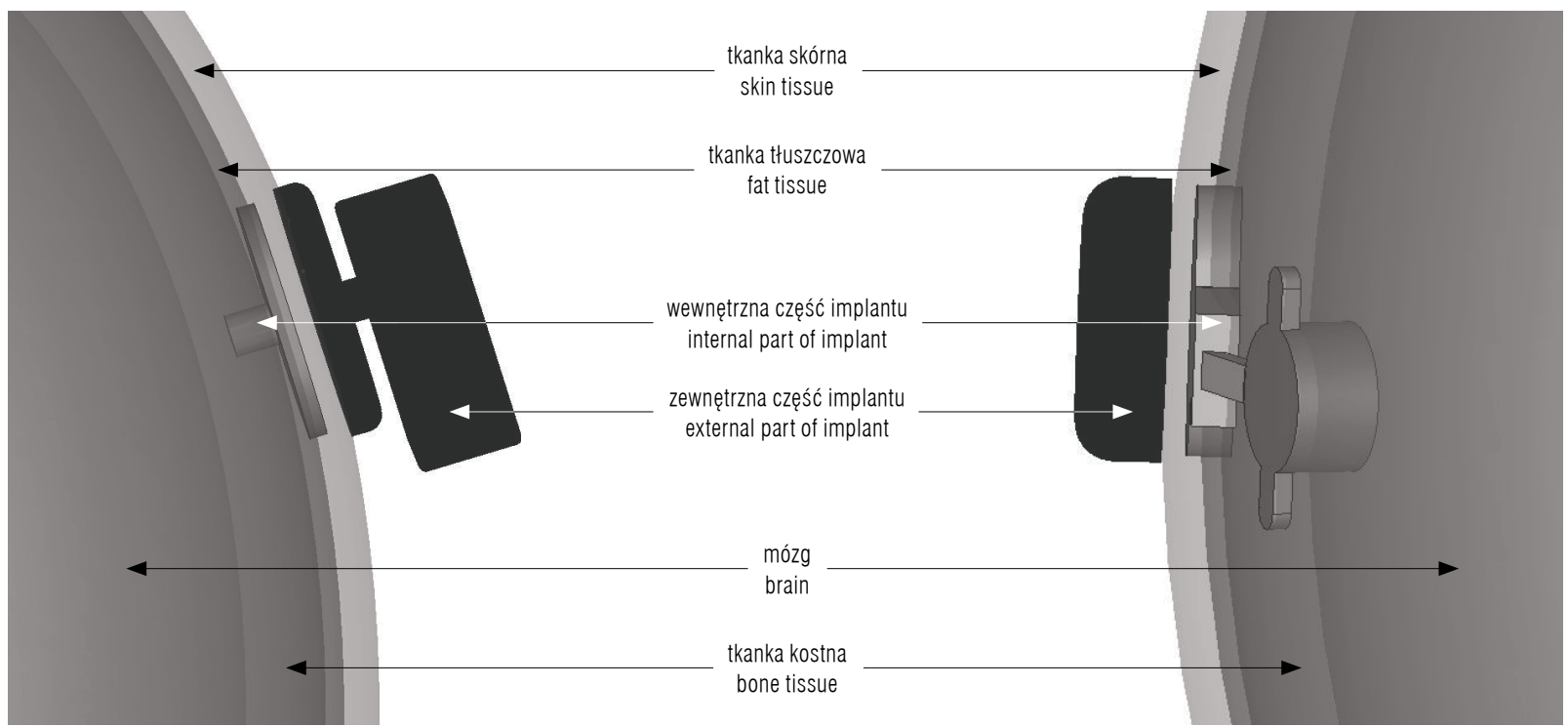

Ryc. 2. Numeryczny model głowy użytkownika implantu słuchu typu: a) IS-BAHA (implantu zakotwiczonego w kości) i b) IS-BB (implantu typu Bonebridge)

Fig. 2. Numerical model of the head of hearing implant user: a) IS-BAHA (bone anchored hearing aid) and b) IS-BB (Bonebridge) type

wnętrznej (implantowanej) (ryc. 2). Modelowane elementy implantów zbudowane są z: miedzi, stali, stopu tytanu 6AL4V, silikonu i politereftalanu etylenu (polyethylene terephthalate - PET) [14-16].

$\mathrm{W}$ analizie zagrożeń związanych z oddziaływaniem pola magnetycznego wykorzystano wyniki symulacji dotyczących natężenia indukowanego pola elektrycznego $\left(\mathrm{E}_{\text {in }}\right)$ w skórze i podskórnej tkance tłuszczowej, ponieważ znajdują się $\mathrm{w}$ nich komórki receptorowe i nerwowe obwodowego układu nerwowego, dla którego określono limity $\mathrm{E}_{\text {in }}$ ze względu na ochronę pracowników przed bezpośrednimi skutkami biofizycznymi oddziaływania pola elektromagnetycznego małych częstotliwości $[7,10]$.

\section{Numeryczne modele ciała użytkownika implantu}

Implanty słuchowe typu IS-BB i IS-BAHA są umieszczane za uchem użytkownika. W związku z tym rozpatrywany model numeryczny użytkownika został ograniczony do modelu głowy, będącego wielowarstwową elipsoidą o wymiarach odpowiadających głowie 50-centylowego mężczyzny populacji polskiej [17]: wzdłuż osi długiej - $24 \mathrm{~cm}$, poprzecznej - $16 \mathrm{~cm}$ i strzałkowej $-19 \mathrm{~cm}$. Wyróżniono w nim warstwy o parametrach dielektrycznych, przyjęte na podstawie przeglądu danych literaturowych [18], odpowiadających skórze, podskórnej tkance tłuszczowej, tkance kostnej (kości czaszki) i części wewnętrznej odpowiadającej tkance mózgowej (wartość średnia istoty białej i szarej) (ryc. 2). Grubość warstwy skóry $(4 \mathrm{~mm})$ i podskórnej warstwy tkanki tłuszczo- wej ( $2 \mathrm{~mm}$ ) odpowiadały wartościom średnim u osób, którym wszczepiano implanty na przewodnictwo kostne, a kości czaszki (9 mm) - grubości implantowanego w niej elementu $[19,20]$. Wielowarstwowy model głowy został zastosowany ze względu na możliwość kontrolowania grubości poszczególnych warstw modelu oraz ciągłość warstwy skóry. Ciągłość skóry nie jest satysfakcjonująca w wielu obecnie dostępnych modelach anatomicznych, które mają również ustaloną arbitralnie jej grubość oraz grubość tkanki tłuszczowej i kostnej.

\section{Metoda symulacji numerycznych}

Model numeryczny o rozdzielczości ok. 0,3-0,5 mm w otoczeniu modelowanych implantów wykonano specjalistycznym oprogramowaniem do analizy pola elektromagnetycznego CST Studio Suite 2014. Niepewność rozszerzoną ( $\mathrm{K}=2$ ) wyników symulacji numerycznych natężenia indukowanego pola elektrycznego oszacowano zgodnie $\mathrm{z}$ zaleceniami normy międzynarodowej na ok. $\pm 60 \%$ [21]. Jest to typowy poziom niepewności wyników podobnego typu symulacji numerycznych relacjonowany w publikacjach naukowych.

\section{Kryteria oceny zagrożeń elektromagnetycznych}

Bezpośrednie skutki oddziaływania pola magnetycznego na użytkownika implantu oceniono w odniesieniu do limitów określonych w Dyrektywie 2013/35/UE na podstawie wytycznych określonych w zaleceniach ICNIRP [7,11]. Uwzględniono górny graniczny poziom oddziaływania (GPO-UE), będący limitem dla miary 
bezpośrednich skutków oddziaływania pola elektromagnetycznego, tj. maksymalnej wartość $\mathrm{E}_{\text {in }} \mathrm{w}$ obwodowym układzie nerwowym modelu pracownika (tab. 1).

W polskim prawie pracy również określono limity dotyczące $\mathrm{E}_{\text {in }}$ analogicznie do wartość GPO-UE określonych $\mathrm{w}$ dyrektywie (GPO-PL = GPO-UE). Ponadto do oceny narażeń w miejscu pracy określono limity dotyczące indukcji magnetycznej (B) pola oddziałującego na pracownika. Ze względu na zróżnicowane zasady i miary takiej oceny limity dotyczące indukcji magnetycznej są również zróżnicowane (tab. 1).

$\mathrm{W}$ analizie pominięto analogiczne dolne limity oddziaływania, ponieważ są związane ze skutkami oddziaływania na ośrodkowy układ nerwowy, a elementy implantów typu IS-BB oraz IS-BAHA nie mają kontaktu $\mathrm{z}$ tkankami mózgu. Kontakt przewodzącej metalowej struktury implantu z tkankami tłuszczową i kostną oraz ze skórą mają: przetwornik BC-FMT (bone conduction - floating mass transducer, przewodzenie kostne - pływająca masa przetwornika) w IS-BB oraz element implantowany w IS-BAHA. W pobliżu tych elementów występują najsilniejsze skutki bezpośredniego oddziaływania pola elektromagnetycznego.

\section{WYNIKI}

W celu zwalidowania modelu źródła pola i scharakteryzowania scenariusza ekspozycyjnego wykonano pomiary przestrzennego rozkładu indukcji magnetycznej w otoczeniu modelowanego aplikatora. Pomiary wykonano miernikiem Narda ELT 400 (prod. Narda Safety Test Solutions, Niemcy) z typowymi kulistymi sondami izotropowymi o powierzchniach przekroju: $3 \mathrm{~cm}^{2}$ i $100 \mathrm{~cm}^{2}$ (niepewność standardowa pomiarów, odpowiednio, $\pm 6 \%$ i $\pm 4 \%)$.

Wyniki takich pomiarów odpowiadaja miejscowe$\mathrm{mu}$ uśrednianiu pola $\mathrm{w}$ objętości sześciennych sond pomiarowych, o krawędzi, odpowiednio, ok. $10 \mathrm{~cm}$ $\left(\mathrm{SD}_{10 \mathrm{~cm}}\right)$ i ok. $2 \mathrm{~cm}\left(\mathrm{SD}_{2 \mathrm{~cm}}\right)$. Wyniki pomiarów indukcji magnetycznej wykonanych przy powierzchni aplikatora sondami $\mathrm{SD}_{10 \mathrm{~cm}}$ i $\mathrm{SD}_{2 \mathrm{~cm}}$ (tj. uśrednionych miejscowo w różnej wielkości przestrzeni) są odpowiednio mniejsze o $50 \%$ i $25 \%$ od wartości punktowej obliczonej na podstawie symulacji numerycznych rozkładu pola przy aplikatorze. W miarę oddalania się od aplikatora rozbieżności te maleją, a $\mathrm{w}$ odległościach przekraczających $50 \mathrm{~cm}$ sposób oceny nie wpływa istotnie na

Tabela 1. Limity dotyczące narażenia pracowników na pole magnetyczne o częstotliwości $100 \mathrm{~Hz}$ według ICNIRP [11], Dyrektywy 2013/35/UE [7] i polskiego prawa pracy [9,10]

Table 1. Limits regarding workers exposure to magnetic field at $100 \mathrm{~Hz}$ frequency, according to ICNIRP [11], Directive 2013/35/EU [7], and labor legislation in Poland $[9,10]$

Miara
Measure

Miara bezpośredniego oddziaływania - natężenie indukowanego pola elektrycznego /

/ Measure of direct effect - induced electric field strength $[\mathrm{V} / \mathrm{m}](\mathrm{rms})$

GPO-UE (górny graniczny poziom oddziaływania wg Dyrektywy 2013/35/UE /

$0,8^{*}$

/ high exposure limit value set up by Directive 2013/35/EU [7])

GPO-PL (górny graniczny poziom oddziaływania wg polskiego prawa pracy /

/ high exposure limit value set up by labor legislation in Poland $[9,10])$

BR-ICNIRP (limit bazowy wg zaleceń ICNIRP / basic restriction set up by ICNIRP [11])

$0,8^{\star}$

Miara narażenia - indukcja magnetyczna / Measure of exposure - magnetic flux density [T] (rms)

IPN-UE (miara narażenia wg Dyrektywy 2013/35/UE / measure of exposure set up by Directive 2013/35/UE [7])

$0,003^{* *}$

IPN-PL (miara narażenia wg polskiego prawa pracy / measure of exposure set up by labor legislation in Poland $[9,10]$ )

$0,002^{* * *}$

RL-ICNIRP (limit referencyjny wg ICNIRP / reference level set up by ICNIRP [11])

$0,001^{* * * *}$

ICNIRP - Międzynarodowa Komisja ds. Ochrony przed Promieniowaniem Niejonizującym / International Commission on Non-Ionizing Radiation Protection, rms - wartość skuteczna / root-mean-squere value.

* Maksymalna wartość natężenia pola elektrycznego indukowanego przez pole elektromagnetyczne w obwodowym układzie nerwowym pracownika / Maximum value of electric field strength induced by electromagnetic field in the peripheral nervous system of worker.

** Maksymalna obliczona lub zmierzona wartość indukcji magnetycznej niezaburzonego pola magnetycznego oddziałującego na pracownika / Maximum calculated or measured value of magnetic flux density of unperturbed magnetic field influencing worker.

*** Maksymalna wartość indukcji magnetycznej niezaburzonego pola magnetycznego oddziałującego na pracownika, odpowiadająca wynikowi pomiaru referencyjną sondą uśredniającą miejscowo w sześcianie o krawędzi $10 \mathrm{~cm} /$ Maximum value of magnetic flux density of unperturbed magnetic field influencing worker, equivalent to the result of measurements by locally averaging probe in the cubic of $10 \mathrm{~cm}$ size.

**** Uśredniona przestrzennie dla ciała lub jego części wartość indukcji magnetycznej niezaburzonego pola magnetycznego oddziałującego na pracownika / Spatially averaged value of magnetic flux density of unperturbed magnetic field influencing worker's body or part of it. 
wynik pomiaru. Ponadto przy powierzchni aplikatora maksymalna wartość indukcji pola magnetycznego zmierzona $\mathrm{SD}_{10 \mathrm{~cm}}$ różni się o $23 \%$ od wartości średniej $\mathrm{w}$ całej głowie (average value in head - $\mathrm{AH}$ ). Wartość zmierzona $\mathrm{SD}_{2 \mathrm{~cm}}$ różni się natomiast o $82 \%$ od wartości średniej w całej głowie (AH). Różnica ta maleje wraz ze wzrostem odległości od aplikatora.

Wyniki symulacji numerycznych $\mathrm{E}_{\text {in }}$ zwalidowano z danymi literaturowymi, wykorzystując wartości obliczone w mózgu modelu numerycznego bez implantu zlokalizowanego w odległości $50 \mathrm{~cm}$ obok aplikatora. $\mathrm{W}$ takim miejscu wartości pola magnetycznego: maksymalna zmierzona $\mathrm{SD}_{10 \mathrm{~cm}}$ i średnia $\mathrm{w}$ całej głowie, różnią się maksymalnie o $10 \%$. Może to więc być przybliżony model oddziaływania pola jednorodnego, znanego $\mathrm{z}$ danych literaturowych. Parametr K obliczono następująco:

gdzie:

$$
\mathrm{K}=\mathrm{E}_{\text {in }} / \mathrm{B}
$$

$\mathrm{E}_{\text {in }}$ - indukowane pole elektryczne,

B - indukcja magnetyczna oddziałującego pola.

W opisywanym $\mathrm{w}$ piśmiennictwie modelu warstwowym o średnicy $20 \mathrm{~cm}$, w którym uwzględniono warstwy odpowiadające skórze (2 $\mathrm{mm}$ grubości), tkance kostnej $(8 \mathrm{~mm})$ i mózgowi (nie uwzględniono tkanki tłuszczowej), w polu jednorodnym parametr $\mathrm{K}$ obliczono (z niepewnością standardową) w zakresie: $32,8 \pm 11,4(\mathrm{~V} / \mathrm{m}) / \mathrm{T}$ w mózgu, 40,4 $\pm 14,2(\mathrm{~V} / \mathrm{m}) / \mathrm{T}$ w tkance kostnej i 39,8 14 (V/m)/T w skórze - podane wartości przeskalowano do częstotliwości $100 \mathrm{~Hz}$ charakteryzującej rozpatrywane scenariusze narażenia użytkowników implantów medycznych [22].

$\mathrm{W}$ analizowanym $\mathrm{w}$ niniejszej pracy przypadku ekspozycji na pole magnetyczne występujące w odle- głości $50 \mathrm{~cm}$ od aplikatora (tj. pole quasi-jednorodne) w modelu warstwowym (grubość skóry: $4 \mathrm{~mm}$, tkanki kostnej: $9 \mathrm{~mm}$ ) parametr $\mathrm{K} \mathrm{w}$ tkankach mózgu, kostnej i skóry wynosi, odpowiednio: 31,14 $\pm 18,8(\mathrm{~V} / \mathrm{m}) / \mathrm{T}$, $35 \pm 21(\mathrm{~V} / \mathrm{m}) / \mathrm{T}$ i $38 \pm 22,8(\mathrm{~V} / \mathrm{m}) / \mathrm{T}$ - przy określaniu wartości indukcji magnetycznej (B) na podstawie pomiarów $\mathrm{SD}_{10 \mathrm{~cm}}$. Wyniki te są zgodne z oczekiwaniami teoretycznymi - tj. parametr K ma mniejsze wartości $\mathrm{w}$ polu niejednorodnym $\mathrm{w}$ stosunku do uzyskanych w polu jednorodnym. Biorąc pod uwagę zarówno zróżnicowanie porównywanych modeli, jak i wspomnianą niepewność wyników symulacji, wyniki można traktować jako zbieżne.

$\mathrm{W}$ tabeli 2. przedstawiono wyniki obliczeń $\mathrm{E}_{\text {in }}$ w numerycznym modelu głowy użytkowników implantów IS-BB lub IS-BAHA unormowane w odniesieniu do wartości uzyskanych dla analogicznego numerycznego modelu głowy bez implantu.

Jak wspomniano, wartości $E_{\text {in }} w$ tkankach mózgu nie są modyfikowane przez obecność implantów IS-BB i IS-BAHA, ponieważ ich elementy nie mają $\mathrm{z}$ nimi kontaktu (ryc. 2). W dalszej części artykułu przeanalizowano skutki elektrodynamiczne oddziaływania pola magnetycznego w pozostałych tkankach.

Wartości parametru $\mathrm{K}$ obliczonego na podstawie wyników symulacji $\mathrm{E}_{\text {in }} \mathrm{w}$ skórze użytkownika IS-BB odniesionych do poziomu narażenia na pole magnetyczne (ocenianego na podstawie pomiarów $\mathrm{SD}_{10 \mathrm{~cm}}$ ) wynosiły $162 \pm 97(\mathrm{~V} / \mathrm{m}) / \mathrm{T}$, a w skórze użytkownika IS-BAHA - 212 \pm 127 (V/m)/T (ryc. 3).

\section{OMÓWIENIE}

Wyniki badań wskazują na występowanie istotnie większych bezpośrednich skutków oddziaływania pola

Tabela 2. Natężenie pola elektrycznego $\left(\mathrm{E}_{\mathrm{in}}\right)$ indukowanego przez pole magnetyczne (o rozkładzie przestrzennym jak przy aplikatorze magnetoterapeutycznym) w modelu głowy użytkownika implantu słuchowego w zależności od typu implantu

Table 2. Electric field strength $\left(\mathrm{E}_{\mathrm{in}}\right)$ induced by magnetic field (of spatial distribution like near the magnetotherapy applicator) inside the model of hearing implant user head according to the implant type

\begin{tabular}{|c|c|c|}
\hline \multirow{2}{*}{$\begin{array}{l}\text { Tkanka } \\
\text { Tissue }\end{array}$} & \multicolumn{2}{|c|}{$\mathrm{E}_{\mathrm{in}}(\mathrm{MI}) / \mathrm{E}_{\mathrm{in}}(\mathrm{M})$} \\
\hline & IS-BB & IS-BAHA \\
\hline Skórna / Skin & 3,4 & 3,9 \\
\hline Tłuszczowa / Fat & 1,9 & 3,2 \\
\hline Kostna / Bone & 1,7 & 2,3 \\
\hline Mózgowa / Brain & 1,0 & 1,0 \\
\hline
\end{tabular}

$\mathrm{E}_{\text {in }}(\mathrm{MI})-\mathrm{E}_{\text {in }} \mathrm{w}$ modelu $\mathrm{z}$ implantem / $\mathrm{E}_{\text {in }}$ in model with implant, $\mathrm{E}_{\text {in }}(\mathrm{M})-\mathrm{E}_{\text {in }}$ w modelu bez implantu / $\mathrm{E}_{\text {in }}$ in model without implant.

Inne skróty jak na rycinie 2 / Other abbreviations as in Figure 2. 


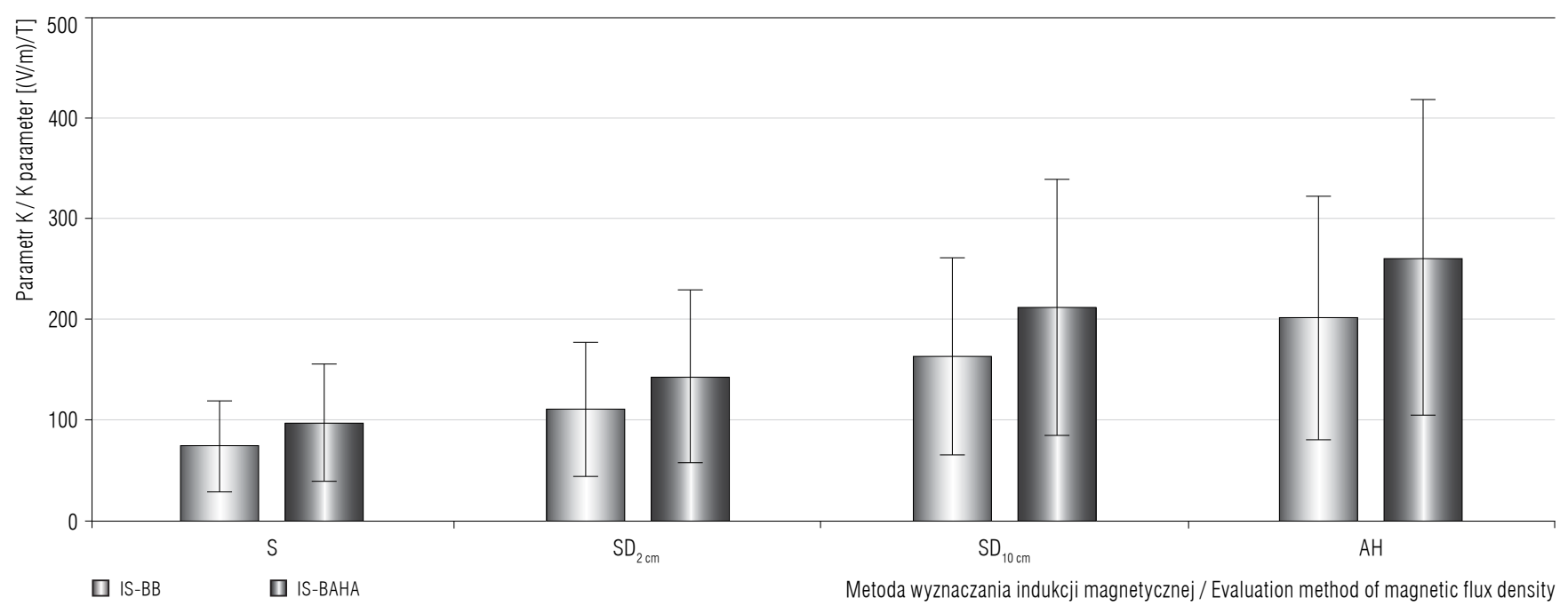

$\mathrm{E}_{\text {in }}$ - indukowane pole elektryczne / induced electrical field, AH - wartość uśredniona dla całej głowy / averaged value for the whole head.

Inne skróty jak na rycinie 1 i 2 / Other abbreviations as in Figures 1 and 2.

Ryc. 3. Parametr $\mathrm{K}=\mathrm{E}_{\mathrm{in}} / \mathrm{B}$ w skórze modelu głowy użytkownika implantu słuchowego określony w zależności od metody wyznaczania wartości indukcji magnetycznej (B) przy powierzchni aplikatora magnetoterapeutycznego o średnicy $25 \mathrm{~cm}$

Fig. 3. The $\mathrm{K}=\mathrm{E}_{\text {in }} / \mathrm{B}$ parameter in skin of head model of hearing implant user for magnetic flux density (B) values according to its evaluation method near the surface of magnetotherapy applicator of $25 \mathrm{~cm}$ in diameter

magnetycznego u użytkowników implantów słuchowych $\mathrm{w}$ porównaniu $\mathrm{z}$ osobami nieużywającymi implantów - niemal 4-krotnie $(3,9)$ dla użytkownika IS-BAHA i 3,4-krotnie dla użytkownika IS-BB.

Wartości $\mathrm{E}_{\text {in }} \mathrm{w}$ modelu głowy użytkownika IS-BAHA były do 70\%, 40\% i 30\% (odpowiednio, w tkance tłuszczowej, kostnej i skórze) większe od wartości obliczonych w modelu głowy użytkownika IS-BB.

Uzyskane wyniki potwierdzają konieczność indywidualnej oceny zagrożeń elektromagnetycznych dotyczących użytkowników implantów słuchowych, którzy zgodnie z postanowieniami Dyrektywy 2013/ /35/UE i transponującego je polskiego prawa pracy należą do pracowników wymagających szczególnej ochrony.

Istotną obserwacją jest, że wartości indukcji magnetycznej w pobliżu aplikatora o średnicy $25 \mathrm{~cm}$ oceniane punktowo (poprzez symulacje numeryczne) i poprzez wartości uśredniane przestrzennie (poprzez wyniki pomiarów sondą izotropową) bywają istotnie rozbieżne w polu o znacznej niejednorodności przestrzennej (np. przy powierzchni aplikatora wartości punktowe i zmierzone $\mathrm{SD}_{10 \mathrm{~cm}}$ różnią się nawet 2 -krotnie). $\mathrm{Z}$ tego względu również wartości parametru $\mathrm{K}=\mathrm{E}_{\text {in }} / \mathrm{B}$, dzięki któremu na podstawie pomiarów indukcji magnetycznej niezaburzonego pola oddziałującego na człowieka można szacować zgodność warunków narażenia $\mathrm{z}$ limitami GPO, są istotnie zależne od przestrzennego rozkładu pola niejednorodnego i metody oceny poziomu narażenia na takie pole.

Dyrektywa 2013/35/UE [7] nie precyzuje sposobu ustalania maksymalnych wartości indukcji magnetycznej pola oddziałującego na pracownika, co może skutkować brakiem spójności wyników oceny zagrożeń na podstawie dopuszczalnych alternatywnie pomiarów i obliczeń dotyczących pola niejednorodnego. Żeby uniknąć tego typu problemów, w polskim prawie pracy określono zasady wyznaczania miejscowej wartości poziomu narażenia jako odpowiednika wyniku pomiaru sondą bezkierunkową w objętości sześcianu o krawędzi $10 \mathrm{~cm}$, niezależnie od stosowanej techniki oceny narażenia pracowników (w drodze pomiarów czy ekwiwalentnych symulacji komputerowych narażenia pracowników).

Wartości parametru $\mathrm{K}$ określone na podstawie limitów narażenia (KL) podanych $\mathrm{w}$ tabeli 1 . wynoszą: KL_UE $=267(\mathrm{~V} / \mathrm{m}) / \mathrm{T}, \mathrm{KL} \_\mathrm{PL}=400(\mathrm{~V} / \mathrm{m}) / \mathrm{T}$ i KL_ICNIRP $=800(\mathrm{~V} / \mathrm{m}) / \mathrm{T}$, odpowiednio dla Dyrektywy 2013/35/UE, polskiego prawa pracy i wytycznych ICNIRP $[7,10,11]$. W przypadku użytkowników IS-BAHA - oddziaływanie pola magnetycznego o rozkładzie przestrzennym porównywalnym $\mathrm{z}$ takim jak w analizowanym przypadku aplikatorów magnetoterapeutycznych - wartości parametru $\mathrm{K}$ mogą być większe od wartości KL_UE (uwzględniając niepewność wyników symulacji numerycznych). 
Wskazuje to, że mimo uzyskania wyników pomiarów $\mathrm{SD}_{10 \mathrm{~cm}}$ niższych od limitów indukcji magnetycznej określonych przez Dyrektywę 2013/35/UE (IPN-UE) [7] bezpośrednie skutki oddziaływania pola magnetycznego w organizmie pracownika mogą przekraczać określone w niej limity indukowanego pola elektrycznego (GPO-UE). Nie stwierdzono zagrożenia nadmiernymi skutkami oddziaływania pola magnetycznego w przypadku narażenia spełniającego wymagania określone w polskim prawie pracy $\left(\mathrm{K}<\mathrm{KL} \_\mathrm{PL}\right)$ lub wymagania ICNIRP ( $\mathrm{K}<\mathrm{KL} \_$ICNIRP).

Indywidualna ocena zagrożeń elektromagnetycznych wymagana przez Dyrektywę 2013/35/UE (bez określenia szczegółowych rozwiązań dotyczących takiej oceny) dla użytkowników implantów słuchowych, np. w ramach profilaktycznej opieki medycznej pracowników, wymaga uwzględnienia rodzaju implantu, jego parametrów technicznych, indywidualnych nastaw, a także warunków narażenia użytkownika na pola elektromagnetyczne. Oznacza to często konieczność konsultacji poszczególnych przypadków z producentem implantu.

Autorzy niniejszej publikacji zwracają uwagę, że prezentowane wyniki symulacji numerycznych nie dotyczą zagrożeń elektromagnetycznych związanych z wpływem pola elektromagnetycznego na funkcjonowanie układów elektronicznych implantów i nie mogą być stosowane zamiast badań in vivo lub in vitro dotyczących oceny zagrożeń elektromagnetycznych użytkowników implantów.

Omawiane wyniki charakteryzujące zagrożenie dla użytkowników implantów mają również zastosowanie dla pacjentów, u których magnetoterapia może być przeciwwskazana ze względu na użytkowanie protez słuchowych.

\section{WNIOSKI}

W modelach oddziaływania pola elektromagnetycznego stwierdzono istotnie większe zagrożenie dla użytkownika implantu słuchowego $\mathrm{w}$ porównaniu $\mathrm{z}$ osobą bez implantu, niemal 4-krotne u użytkownika narażonego na niejednorodne przestrzennie pole magnetyczne, którego źródłem był aplikator magnetoterapeutyczny o średnicy $25 \mathrm{~cm}$. Podobnej skali zwiększenia zagrożeń należy się spodziewać przy innych źródłach pola magnetycznego o zbliżonych parametrach rozkładu przestrzennego narażenia.

Stwierdzono zależność poziomu zagrożeń użytkownika implantu słuchowego od jego typu oraz rozwiązań konstrukcyjnych i technologicznych.
Prezentowane wyniki potwierdzają konieczność spełnienia wymagań Dyrektywy 2013/35/UE [7] i transponującego ją polskiego prawa pracy $[9,10]$ dotyczących indywidualnego rozpatrzenia zagrożeń elektromagnetycznych w miejscu pracy w ramach ochrony osób szczególnie chronionych (w tym użytkowników implantów medycznych) ze względu na możliwość występowania bezpośrednich skutków oddziaływania pola magnetycznego małych częstotliwości o wartościach wielokrotnie większych niż w przypadku osób niebędących użytkownikami takich implantów.

\section{PIŚMIENNICTWO}

1. Krajowy Program Badań. Założenia do polityki naukowo-technicznej i innowacyjnej państwa. Załącznik do uchwały nr 164/2011 Rady Ministrów z dnia 16 sierpnia 2011 r. DzU z 2010 r. nr 96, poz. 615

2. Tagnola G., Parazzini M., Sibella F., Paglialonga A., Ravazzani P.: Electromagnetic interference and cochlear implants. Ann. I. Super. Sanita 2007;43(3):241-247

3. Fritsch M.H., Naumann I.C., Mosier K.M.: BAHA devices and magnetic resonance imaging scanners. Otol. Neurotol. 2008;29(8):1095-1099, https://doi.org/10.1097/ MAO.0b013e31818201fd

4. Hansson Mild K., Hocking B.: Guidance note: Risk management of workers with medical electronic devices and metallic implants in electromagnetic fields. Int. J. Occup. Safety Ergon. 2008;14(2):217-222, https://doi.org/10.1080/ 10803548.2008.11076763

5. LaSorte N.J., Akunne I.B., Refai H.H.: In vitro protocol to study the electromagnetic interaction of RFIDs and infusion pumps. W: Asia-Pacific Symposium on Electromagnetic Compatibility (APEMC); 12-16 kwietnia 2010; Pekin, Chiny. Symposium, Pekin 2010, https://doi.org/10.1109/ apemc.2010.5475872

6. MED-EL [Internet]: MED-EL, 2017 [cytowany 10 listopada 2015]. Adres: http://www.medel.com/pl

7. Dyrektywa Parlamentu Europejskiego i Rady 2013/35/UE z dnia 26 czerwca 2013 r. w sprawie minimalnych wymagań w zakresie ochrony zdrowia i bezpieczeństwa dotyczących narażenia pracowników na zagrożenia spowodowane czynnikami fizycznymi (polami elektromagnetycznymi). DzU UE z 2013 r., L 179/1

8. Council of the European Union Recommendation of $12 \mathrm{Ju}-$ ly 1999 on the limitation of exposure of the general public to electromagnetic fields (0 Hz to $300 \mathrm{GHz}$ ), 1999/519/EC. Off. J. Eur. Union L 199/59

9. Rozporządzenie Ministra Pracy i Polityki Społecznej z dnia 27 czerwca 2016 r. zmieniające rozporządzenie 
w sprawie najwyższych dopuszczalnych stężeń i natężeń czynników szkodliwych dla zdrowia w środowisku pracy. DzU z 2016 r., poz. 952

10. Rozporządzenie Ministra Rodziny, Pracy i Polityki Społecznej z dnia 29 czerwca 2016 r. w sprawie bezpieczeństwa i higieny pracy przy pracach związanych $\mathrm{z}$ narażeniem na pole elektromagnetyczne. DzU z 2016 r., poz. 950

11. International Commission on Non-Ionizing Radiation Protection: Guidelines for limiting exposure to timevarying electric and magnetic fields $(1 \mathrm{~Hz}-100 \mathrm{kHz})$. Health Phys. 2010;99(6):818-836

12. Zradziński P., Karpowicz J., Gryz K., Leszko W.: Badania modelowe i ocena zagrożeń, dotyczące użytkowników wybranych częściowo implantowanych OUM, związanych $\mathrm{z}$ występującymi w środowisku przemysłowym i medycznym elektromagnetycznymi polami oraz opracowanie wstępnego raportu na temat takich zagrożeń. Sprawozdanie $\mathrm{z}$ realizacji II etapu zadania nr II.P.14. Centralny Instytut Ochrony Pracy - Państwowy Instytut Badawczy, Warszawa 2015

13. Gryz K., Leszko W., Karpowicz J.: Narażenie na pole elektromagnetyczne $\mathrm{w}$ otoczeniu aplikatorów urządzeń magnetoterapeutycznych. Probl. Hig. Epidemiol. 2015; 96(3):578-585

14. Modjarrad K., Ebnesaijad S.: Handbook of polymer applications in medicine and medical devices. Elsevier Science \& Technology, Oxford 2013

15. Computer Simulation Technology [Internet]: Computer Simulation Technology, 2016 [cytowany 10 listopa- da 2015]. CST EM Studio. Adres: https://www.cst.com/ products/cstems

16. Arconic [Internet]: Arconic, 2017 [cytowany 10 listopada 2015]. Adres: https://www.arconic.com/global/en/home.asp

17. Gedliczka A.: Atlas miar człowieka - dane do projektowania i oceny ergonomicznej. Centralny Instytut Ochrony Pracy - Państwowy Instytut Badawczy, Warszawa 2001

18. Gabriel S., Lau R.W., Gabriel C.: The dielectric properties of biological tissues: II. Measurements in the frequency range $10 \mathrm{~Hz}$ to $20 \mathrm{GHz}$. Phys. Med. Biol. 1996;41:2251-2269, https://doi.org/10.1088/0031-9155/41/11/002

19. Nevoux J., Ayache D., Coudert C., Czajka C., Meller R., Rossetto S. i wsp.: A new transcutaneous bone-conducting auditory implant: A multicenter preliminary experience. W: 13th International Conference on Cochlear Implants and Other Implantable Auditory Technologies; 18-21 czerwca 2014; Monachium, Niemcy. Ludwig-Maximilians-Universität München, Monachium 2014, s. 452

20. Ruan J., Prasad P.: The effects of skull thickness variations on human head dynamic impact responses. Stapp Car Crash J. 2001;45(12):395-414

21. PN-EN 50413:2009. Metody pomiaru i obliczeń ekspozycji ludzi w polach elektrycznych, magnetycznych i elektromagnetycznych $(0 \mathrm{~Hz}-300 \mathrm{GHz})$. Polski Komitet Normalizacyjny, Warszawa 2009

22. Hirata A., Takano Y., Fujiwara O., Dovan T., Kavet R.: An electric field induced in the retina and brain at threshold magnetic flux density causing magnetophosphenes. Phys. Med. Biol. 2011;56(13):4091-4101, https://doi.org/ $10.1088 / 0031-9155 / 56 / 13 / 022$

Ten utwór jest dostępny w modelu open access na licencji Creative Commons Uznanie autorstwa - Użycie niekomercyjne 3.0 Polska / This work is available in Open Access model and licensed under a Creative Commons Attribution-NonCommercial 3.0 Poland License - http://creativecommons.org/ licenses/by-nc/3.0/pl. 